\title{
Potential Beetle Vectors of Sirococcus clavigignenti-juglandacearum on Butternut
}

\author{
S. Halik, Research Field Technician, and D. R. Bergdahl, Professor, School of Natural Resources, Aiken Center, \\ University of Vermont, Burlington 05405
}

\begin{abstract}
Halik, S., and Bergdahl, D. R. 2002. Potential beetle vectors of Sirococcus clavigignentijuglandacearum on butternut. Plant Dis. 86:521-527.

To identify potential beetle (Coleoptera) vectors of the butternut canker fungus (Sirococcus clavigignenti-juglandacearum), beetles were collected from butternut (Juglans cinerea) trees and freshly cut logs and branches in Vermont from 1997 through 1999. At least 17 species of beetles, representing eight families, were found to carry conidia of the pathogen. Species most commonly collected and most frequently carrying the fungus were Acoptus suturalis (Curculionidae), Astylopsis macula (Cerambycidae), Eubulus parochus (Curculionidae), and Hyperplatys maculata (Cerambycidae). In 1999, 64, 74, 37, and 52\% of these species, respectively, were carrying conidia. These beetles were often collected from dead butternut stems and branches upon which the fungus was fruiting and were less frequently found in crowns of living butternut trees. The butternut curculio (Conotrachelus juglandis) (Curculionidae) was found creating feeding and oviposition wounds on new shoots in crowns of butternut trees. Six to eleven percent of curculios collected carried the fungus. Species of Nitidulidae were observed crawling on logs or burrowing into cankers and curculio wounds. Six to seven percent of the nitidulids, Cryptarcha ampla and Glischrochilus sanguinolentus, carried conidia in 1999, and $31 \%$ of G. vittatus carried the fungus in 1998. Additional study is necessary to learn how consistently any of these beetles move from diseased to healthy tissue of butternut and vector conidia of S. clavigignenti-juglandacearum.
\end{abstract}

Additional keywords: Glischrochilus fasciatus, G. quadrisignatus, G. siepmanni, longhorned beetle, Melanconis juglandis, Melanconium oblongum, Paria sp., sap-feeding beetle, weevil

Since its discovery in Wisconsin in 1967 (22), butternut canker, caused by the fungus Sirococcus clavigignenti-juglandacearum Nair, Kostichka, \& Kuntz, has been reported throughout the entire range of butternut (Juglans cinerea L.) in the eastern half of the United States and southeastern Canada (19). Because of the apparently rapid movement of this pathogen, its extreme virulence, its lack of genetic diversity, and the limited resistance displayed by the host, the fungus is believed to be an exotic species of unknown origin that was introduced to North America $(7,19)$.

Dissemination of the fungus occurs by movement of conidia, which may infect through wounds or other openings in the bark of butternut. Infection results in formation of sunken, elliptical cankers on branches, stems, and buttress roots. If large cankers (or several smaller, coalescing cankers) form, branches and twigs become girdled, resulting in dieback. The stem or buttress roots can also become girdled, ultimately killing the tree $(26,28)$.

Corresponding author: S. Halik

E-mail: shalik@snr.uvm.edu

Accepted for publication 3 February 2002.

Publication no. D-2002-0318-03R

(C) 2002 The American Phytopathological Society
On cankered areas of the tree, hyphal pegs or stromatal columns of the fungus cause the bark to lift and split. Conidia are extruded in gelatinous cirri from pycnidia produced amid the stromatal columns. Fruiting structures and conidia are more likely to develop on dead branches than on cankered areas of the stem (28), and rain splash and stem runoff spread spores to lower portions of the tree (27). Impact from rain can disseminate conidia short distances and, in combination with wind, may form aerosols, which may then disseminate conidia longer distances (27). Rain splash and wind have been shown to spread conidia up to about $45 \mathrm{~m}$; however, longer distances may be possible (17).

Air movement of fungal spores is considered a random event (14), and the density of conidia of $S$. clavigignentijuglandacearum decreases exponentially with increasing distance from the inoculum source (27). Because the fungus has spread quickly and efficiently throughout the range of a tree species that grows in isolated, scattered clumps, it has been hypothesized that a vector specifically targeting butternut trees is involved. Speculation has centered on birds and insects (1,19). Sap-feeding beetles (Coleoptera: Nitidulidae), well-known vectors of spores of Ceratocystis fagacearum (Bretz) Hunt, the fungus causing oak wilt disease $(9,11)$, are one example of a potential vector. Certainly, the sticky conidia of $S$. clavigignenti-juglandacearum could adhere easily to the exoskeleton of winged insects and be transported to butternut trees well beyond distances attributed to movement by rain splash.

In 1994, we began surveying for insects associated with butternut trees. Midway through collections in 1996, we were consistently isolating and identifying the butternut canker fungus from certain beetle species, and preliminary results were published $(1,10)$. From 1997 to 1999, we concentrated on examining adults of beetle species collected from freshly cut and living butternut trees infected with the pathogen. Our objectives were to determine the percentage of individuals of each beetle species that carried conidia, the approximate numbers they carried, and the period of time that each species carried spores.

\section{MATERIALS AND METHODS}

Beetle collection. In 1997 (24 April to 14 October) and 1998 (1 May to 13 October), two or three times per week, we looked for and collected any beetles associated with diseased butternut trees at two sites in northern Vermont. Our first site (University of Vermont Research Forest in Jericho, VT) is a mixed northern hardwood forest type with a heavy component of native conifers and blocks of exotic conifer plantings. Mature trees and saplings of butternut are located in scattered clumps throughout the forest. Beetles were collected from two debris locations, where we piled 10 to 20 logs and large branches of freshly cut, diseased butternut beneath mature, living (but diseased) butternut trees. Our second site (town forest in Berlin, VT), located approximately $50 \mathrm{~km}$ east-southeast of the Jericho site, is also a mixed northern hardwood forest type containing a large component of mature butternut trees, some of which appear relatively healthy. At this site, four debris locations containing 5 to 10 freshly cut butternut logs and branches were used for beetle collection in 1997 and 1998. In 1999 (27 April to 27 September), we looked for and collected beetles three times per week from three debris locations only at the Jericho site. Beetles were found either on butternut logs and branches on the ground or on stems, lower branches, epicormic shoots, and buttress roots of standing butternut trees. Using a sterile, disposable, wooden toothpick, we removed each beetle and placed it into a sterile, labeled vial for transport in a cooler to the laboratory.

To collect beetles from the upper crowns of eight living butternut trees twice a week 
at the Jericho site, we used a 7.5-m extension pole to shake all reachable branches and collected fallen beetles from a $6 \times 7.5$ $\mathrm{m}$ sheet of clear plastic spread on the ground beneath the trees. To collect nitidulids, we suspended six Lindgren funnel traps (Phero Tech, Inc., Delta, BC, Canada) and five Multi-pher traps (BioControl Services, Ste Foy, PQ, Canada) from or adjacent to diseased butternut trees at the Jericho site in 1998. Each trap was baited with raw bread dough to attract nitidulids, following the methods of Williams et al. (30). In 1999, we suspended two baited Lindgren funnel traps from one diseased butternut tree at the Jericho site. Two to three times a week, captured beetles were placed in vials using sterile forceps. Because of the large quantity of nitidulids trapped, more than one individual was often placed in a single vial for processing.

To determine a possible relationship between precipitation and number and frequency of conidia carried by the various beetle species, we used NOAA National Climatic Data Center local climatological data collected at the Burlington International Airport (13 km west-northwest of the Jericho site) in 1997 (16). In 1998 and 1999, precipitation was recorded, using a tipping bucket rain gauge and event recorder (Weathermeasure Corp., Sacramento, CA), at the Jericho site.

Beetle processing. In the laboratory on the day of collection, each beetle vial was numbered; and species identification, location, and date of collection were recorded. Vials were wiped with $70 \%$ ethanol and placed in a microbiological hood where 0.4 $\mathrm{ml}$ of sterile distilled water was added to each vial. Vials were swirled gently to dislodge spores adhering to the beetles, and each beetle was then removed from its vial with sterile forceps. In 1997, each beetle was allowed to crawl in a petri plate containing $2 \%$ water agar and was then crushed in a second water agar plate. Two sterile, wire loopsful of water from each vial were streaked onto one petri plate containing $1.5 \%$ malt agar in 1997 and onto each of two plates in 1998 and 1999. Plates were incubated in the dark at $20^{\circ} \mathrm{C}$ and observed after 2 weeks using a dissecting microscope. We identified colonies of S. clavigignenti-juglandacearum by characteristic pycnidia and cirri of conidia. Spores were then viewed microscopically at $\times 400$ to confirm identification.

The remaining water in each vial was fixed with $0.1 \%$ aniline blue in $50 \%$ lactic acid and stored at $4^{\circ} \mathrm{C}$ for up to 6 months until processed. A microscope slide was then prepared from the stained rinse water and viewed at $\times 100$ and $\times 400$ to identify conidia of $S$. clavigignenti-juglandacearum. If conidia were found on the slide, we used a hemacytometer to estimate the total number of spores carried by each beetle (29). Our counting method limited the minimum number of estimated conidia to 200 . When spore numbers were low,

Table 1. Beetles (Coleoptera) collected on butternut (Juglans cinerea) from Jericho, VT, in 1997, 1998, and 1999 and from Berlin, VT, in 1997 and 1998 and number carrying conidia of Sirococcus clavigignenti-juglandacearum

\begin{tabular}{|c|c|c|c|}
\hline \multirow{2}{*}{$\begin{array}{l}\text { Order } \\
\text { Family } \\
\text { Species }\end{array}$} & \multicolumn{3}{|c|}{$\begin{array}{c}\text { Number of beetles carrying conidia/ } \\
\text { total collected }(\%)\end{array}$} \\
\hline & 1997 & 1998 & 1999 \\
\hline \multicolumn{4}{|l|}{ Coleoptera } \\
\hline \multicolumn{4}{|l|}{ Cerambycidae } \\
\hline Astylopsis macula (Say) & $126 / 286(44)$ & $189 / 473(40)$ & $247 / 335(74)$ \\
\hline Hyperplatys maculata Haldeman & $29 / 115(25)$ & $39 / 172(23)$ & $158 / 304(52)$ \\
\hline Microgoes oculates (LeConte) & $1 / 1(100)$ & $0 / 0(0)$ & $8 / 8(100)$ \\
\hline Urgleptes spp. & $5 / 14(36)$ & $1 / 6(17)$ & $8 / 15(53)$ \\
\hline \multicolumn{4}{|l|}{ Chrysomelidae } \\
\hline Paria sp. & $0 / 0(0)$ & $1 / 6(17)$ & $24 / 229(10)$ \\
\hline \multicolumn{4}{|l|}{ Curculionidae } \\
\hline Acoptus suturalis LeConte & $7 / 29(24)$ & $20 / 119(17)$ & $69 / 108(64)$ \\
\hline Conotrachelus juglandis LeConte & $3 / 54(6)$ & $4 / 38(11)$ & $13 / 178(7)$ \\
\hline Cossonus platalea Say & $3 / 52(6)$ & $3 / 61(5)$ & $4 / 32(12)$ \\
\hline Eubulus parochus (Herbst) & $150 / 396(38)$ & $147 / 471(31)$ & $93 / 252(37)$ \\
\hline Myrmex chevrolati (Horn) & $0 / 0(0)$ & $1 / 1(100)$ & $1 / 1(100)$ \\
\hline Elateridae $^{\mathrm{a}}$ & $0 / 7(0)$ & $2 / 37(5)$ & $2 / 6(33)$ \\
\hline Leiodidae $^{\mathrm{b}}$ & $0 / 0(0)$ & $3 / 11(27)$ & $0 / 4(0)$ \\
\hline \multicolumn{4}{|l|}{ Nemonychidae } \\
\hline Neocimberis elongatus LeConte & $1 / 3(33)$ & $6 / 51(12)$ & $3 / 6(50)$ \\
\hline Nitidulidae $^{c}$ & $1 / 50(2)$ & $17 / 778(2)$ & $\ldots^{\mathrm{d}}$ \\
\hline Cryptarcha ampla Erichson & & & $2 / 31(6)$ \\
\hline Glischrochilus sanguinolentus (Olivier) & & & $5 / 69(7)$ \\
\hline Glischrochilus vittatus (Say) & $0 / 0(0)$ & $4 / 13(31)$ & $0 / 0(0)$ \\
\hline Scolytidae $^{\mathrm{a}}$ & $0 / 6(0)$ & $1 / 30(3)$ & $0 / 7(0)$ \\
\hline
\end{tabular}

${ }^{a}$ Family represents more than one unidentified species.

${ }^{\mathrm{b}}$ Family represents one unidentified species.

${ }^{\mathrm{c}}$ Combined collection of Cryptarcha ampla Erichson, Glischrochilus fasciatus (Olivier), G. quadrisignatus (Olivier), G. sanguinolentus (Olivier), and G. siepmanni W.J. Brown.

${ }^{\mathrm{d}}$ Nitidulidae separated by species in 1999 . there were instances when conidia were viewed on the microscope slide but were not present on the hemacytometer; and a count could not be made. We classified beetles as carrying conidia if any agar plates were positive for the fungus or if we observed stained conidia on the microscope slide. Identifications of beetle species found carrying the fungus were confirmed by R. T. Bell (Entomologist, Department of Biological Sciences, University of Vermont, Burlington).

\section{RESULTS}

We collected 1,095 beetles in 1997, 2,334 beetles in 1998 , and 1,699 beetles in 1999. At least 17 species of beetles, representing eight families, were found to carry conidia of $S$. clavigignenti-juglandacearum. Most species belonged to the families Cerambycidae (longhorned beetles) or Curculionidae (weevils) (Table 1). Total conidia numbers estimated per beetle ranged from 200 to 1.6 million (Table 2). The frequency of infestation with the fungus for an individual beetle species ranged from 2 to $100 \%$; however, beetles found carrying the fungus $100 \%$ of the time were never collected in large numbers $(<9$ per year) (Table 1). Beetles found in greatest abundance from freshly cut or fallen logs and branches included: Acoptus suturalis LeConte (Curculionidae), Astylopsis macula (Say) (Cerambycidae), Eubulus parochus (Herbst) (Curculionidae), and Hyperplatys maculata Haldeman (Cerambycidae). The beetles most commonly collected by shaking branches in the crowns of live trees included: the butternut curculio (Conotrachelus juglandis LeConte (Curculionidae)), $H$. maculata, and Paria sp. (Chrysomelidae) (Table 3).

Of these six beetle species, those with the most consistently high rates of infestation with the pathogen were the cerambycids Astylopsis macula and H. maculata, and the curculionids Acoptus suturalis and E. parochus (Table 1). The 1997 isolation procedure included allowing each beetle to walk on a water agar plate and then crushing each beetle on a separate plate. Growth of $S$. clavigignenti-juglandacearum on these plates was limited. For Astylopsis macula, E. parochus, and H. maculata, $\leq 5 \%$ of the individuals within each species were positive for the fungus, based on growth on either of these two plates. However, based on growth on malt agar plates on which rinse water was streaked, 18 to $30 \%$ of each of these three beetle species were positive for the fungus. Similar results were obtained from streaked plates in 1998 and 1999. For all 3 years, percentages of beetles found carrying conidia based on examination of stained rinse water were comparable to percentages based on growth of the fungus on streaked plates. Conidia of Melanconium oblongum Berk. (teleomorph Melanconis juglandis (E. \& E.) Graves), commonly found fruiting on 
dead twigs and branches of butternut, were also frequently rinsed from these beetle species.

Astylopsis macula carried S. clavigignentijuglandacearum most frequently each year (Table 1). There was approximately a twofold increase in the percentage of $\mathrm{A}$. $\mathrm{mac}$ ula carrying the fungus in 1999 compared with 1997 and 1998. Of all the insects collected, this species carried the greatest number of conidia (up to 1.6 million) (Table 2). A. macula first emerged from dead butternut $\operatorname{logs}$ and limbs in late May to mid-June and carried conidia until late August at the Jericho site (Fig. 1). The last individuals were found in late September at the Jericho site and early October at the Berlin site, but they were not carrying conidia. We observed the beetle feeding on the dead bark of logs, branches, and twigs and on fungi, including $S$. clavigignentijuglandacearum and $M$. oblongum, which were fruiting on dead twigs and branches of butternut. Individuals of A. macula, carrying conidia, were collected from the crowns of butternut trees, but we did not observe them feeding on the bark of living branches. Greater numbers of A. macula were shaken from crowns in 1999 than in 1997 or 1998; and in 1999, these beetles were frequently infested with conidia (Table 3 ).

H. maculata first emerged from dead butternut $\operatorname{logs}$ and limbs in early to late June and carried conidia until late August at the Jericho site (Fig. 2). The last individuals were found in early September at the Jericho site and in early October at the Berlin site. Conidia were found on beetles from the Berlin site until early September. This cerambycid also appeared to feed on dead bark and fungi on twigs, branches, and logs of butternut. The percentage of individuals carrying conidia in 1999 was more than twice that recorded in 1997 and 1998 (Table 1). Also in 1999, this beetle was more commonly collected from crowns than from logs and branches on the ground, and a greater percentage of beetles from the crowns carried $S$. clavigignentijuglandacearum (Table 3). Of the four most abundant beetles found on dead wood, H. maculata was most frequently collected from tree crowns; however, we did not observe its activity in the crowns.

Of the two curculionids, Acoptus suturalis and $E$. parochus, we only observed larvae of $E$. parochus beneath the bark of dead stems and large-diameter branches, often in areas containing stromatal columns of the butternut canker fungus. Larvae of E. parochus pupated by late summer or early fall and then emerged as adults to overwinter. Both curculionids were observed to feed on dead bark and fungi, including $S$. clavigignenti-juglandacearum and $M$. oblongum, on logs, branches, and twigs of butternut. Both weevils were found to carry conidia when collected from crowns of live butternut trees (Table 3), but we do not know if the beetles are ever associated with living branches. Adults of E. parochus that had overwintered were first found in early May, and they carried conidia from then until mid-September at the Jericho site (Fig. 3). Individuals were collected as late as mid-October and they carried conidia until early October at the Berlin site. Over $30 \%$ of these weevils were found infested with the butternut canker fungus each year (Table 1), and individuals carried as many as 780,000 spores (Table 2).

Acoptus suturalis carried conidia each year, and in 1999 the percentage carrying spores was three times as great as in 1997 or 1998 (Table 1). This weevil was first found in early May to early June and carried conidia until early August (Fig. 4). Individuals were found as late as midAugust.

Butternut curculios were almost exclusively collected from tree crowns. From 1997 to 1999,6 to $11 \%$ carried $S$. clavigignenti-juglandacearum (Table 1); however, the numbers of conidia they carried were relatively small (Table 2). This weevil first appeared in early May to early June and carried conidia as late as midAugust; however, individuals were found as late as early October. The greatest numbers of individuals were found in May and June and the percentages carrying conidia

Table 3. Beetles (Coleoptera) collected, by shaking branches of live butternut trees in Jericho, VT, and found carrying conidiospores of Sirococcus clavigignenti-juglandacearum in 1997, 1998, and 1999

\begin{tabular}{|c|c|c|c|}
\hline \multirow{2}{*}{$\begin{array}{l}\text { Family } \\
\text { Species }\end{array}$} & \multicolumn{3}{|c|}{$\begin{array}{l}\text { Number of beetles carrying conidia/ } \\
\text { total collected }(\%)\end{array}$} \\
\hline & 1997 & 1998 & 1999 \\
\hline \multicolumn{4}{|l|}{ Cerambycidae } \\
\hline Astylopsis macula (Say) & $0 / 2(0)$ & $2 / 2(100)$ & $47 / 57(82)$ \\
\hline Hyperplatys maculata Haldeman & $1 / 1(100)$ & $8 / 21(38)$ & $117 / 207(57)$ \\
\hline Urgleptes spp. & $0 / 0(0)$ & $0 / 0(0)$ & $1 / 3(33)$ \\
\hline \multicolumn{4}{|l|}{ Chrysomelidae } \\
\hline Paria sp. & $0 / 0(0)$ & $1 / 4(25)$ & $23 / 225(10)$ \\
\hline \multicolumn{4}{|l|}{ Curculionidae } \\
\hline Acoptus suturalis LeConte & $0 / 1(0)$ & $0 / 1(0)$ & $14 / 24(58)$ \\
\hline Conotrachelus juglandis LeConte & $3 / 53(6)$ & $3 / 33(9)$ & $12 / 174(7)$ \\
\hline Eubulus parochus (Herbst) & $2 / 3(67)$ & $2 / 2(100)$ & $5 / 11(45)$ \\
\hline Myrmex chevrolati (Horn) & $0 / 0(0)$ & 1/1 (100) & $1 / 1(100)$ \\
\hline Elateridae $^{\mathrm{a}}$ & $0 / 3(0)$ & $0 / 2(0)$ & $1 / 1(100)$ \\
\hline Nitidulidae $^{\mathrm{b}}$ & $0 / 39(0)$ & $0 / 11(0)$ & $\ldots{ }^{c}$ \\
\hline Glischrochilus sanguinolentus Olivier & & & $3 / 9(33)$ \\
\hline
\end{tabular}

Table 2. Estimated number of conidia of Sirococcus clavigignenti-juglandacearum on the most frequently collected beetles (Coleoptera) found carrying conidia in 1997, 1998, and 1999 from Jericho, VT, and in 1997 and 1998 from Berlin, VT

\begin{tabular}{|c|c|c|c|}
\hline \multirow{2}{*}{$\begin{array}{l}\text { Family } \\
\text { Species }\end{array}$} & \multicolumn{3}{|c|}{ Mean number of conidia carried (range $\left.{ }^{a}\right) n^{b}$} \\
\hline & 1997 & 1998 & 1999 \\
\hline \multicolumn{4}{|l|}{ Cerambycidae } \\
\hline Astylopsis macula & $14,900(200-620,000) 86$ & $102,800\left(200-1.5 \times 10^{6}\right) 119$ & $135,200\left(200-1.6 \times 10^{6}\right) 209$ \\
\hline Hyperplatys maculata & $5,100(2,000-9,800) 6$ & $9,500(200-49,400) 19$ & $27,000(200-188,200) 82$ \\
\hline Microgoes oculates & $400 n=1$ & $\ldots^{c}$ & $53,700(3,000-145,000) 7$ \\
\hline Urgleptes spp. & $1,200(800-1,600) 3$ & $\mathrm{n}=0^{\mathrm{d}}$ & $17,100(200-112,000) 8$ \\
\hline \multicolumn{4}{|l|}{ Curculionidae } \\
\hline Acoptus suturalis & $2,000(400-5,000) 6$ & $200 n=1$ & $1,300(200-4,200) 18$ \\
\hline Conotrachelus juglandis & $\mathrm{n}=0$ & $\mathrm{n}=0$ & $300(200-400) 2$ \\
\hline Eubulus parochus & $15,800(200-660,000) 74$ & $19,200(200-780,000) 52$ & $1,400(200-13,000) 43$ \\
\hline
\end{tabular}

\footnotetext{
${ }^{a}$ Minimum number of conidiospores that could be estimated was 200.

${ }^{b}$ Number of beetles which carried countable (200 or more) conidiospores.

${ }^{\mathrm{c}}$ No beetles collected.

${ }^{\mathrm{d}}$ Beetles collected were not carrying countable conidiospores.
} 

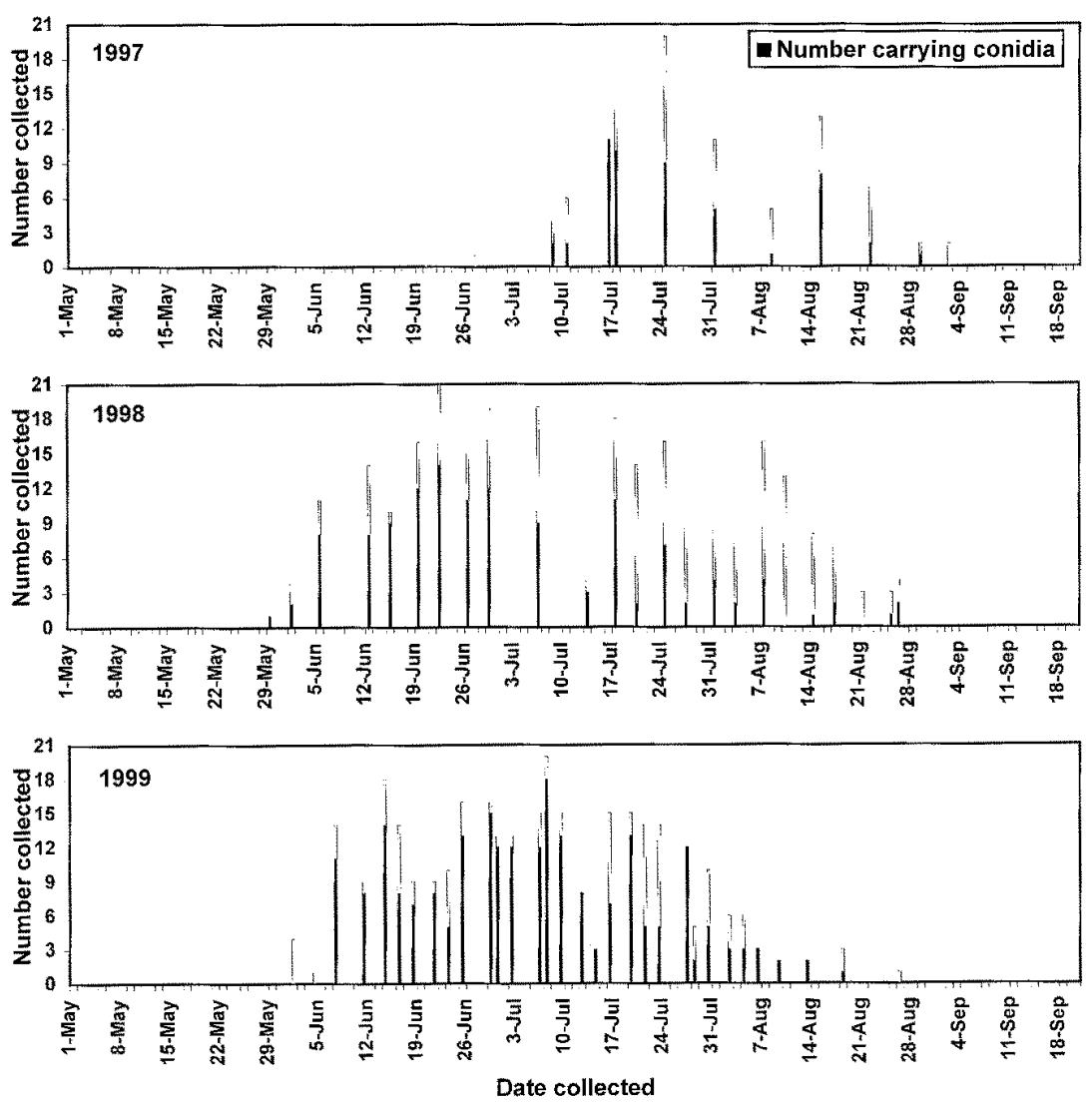

Fig. 1. Numbers of Astylopsis macula collected by date in Jericho, VT, in 1997, 1998, and 1999 Entire bar represents total number of individuals collected. Black portion of bar represents number of individuals found to carry conidia of Sirococcus clavigignenti-juglandacearum.
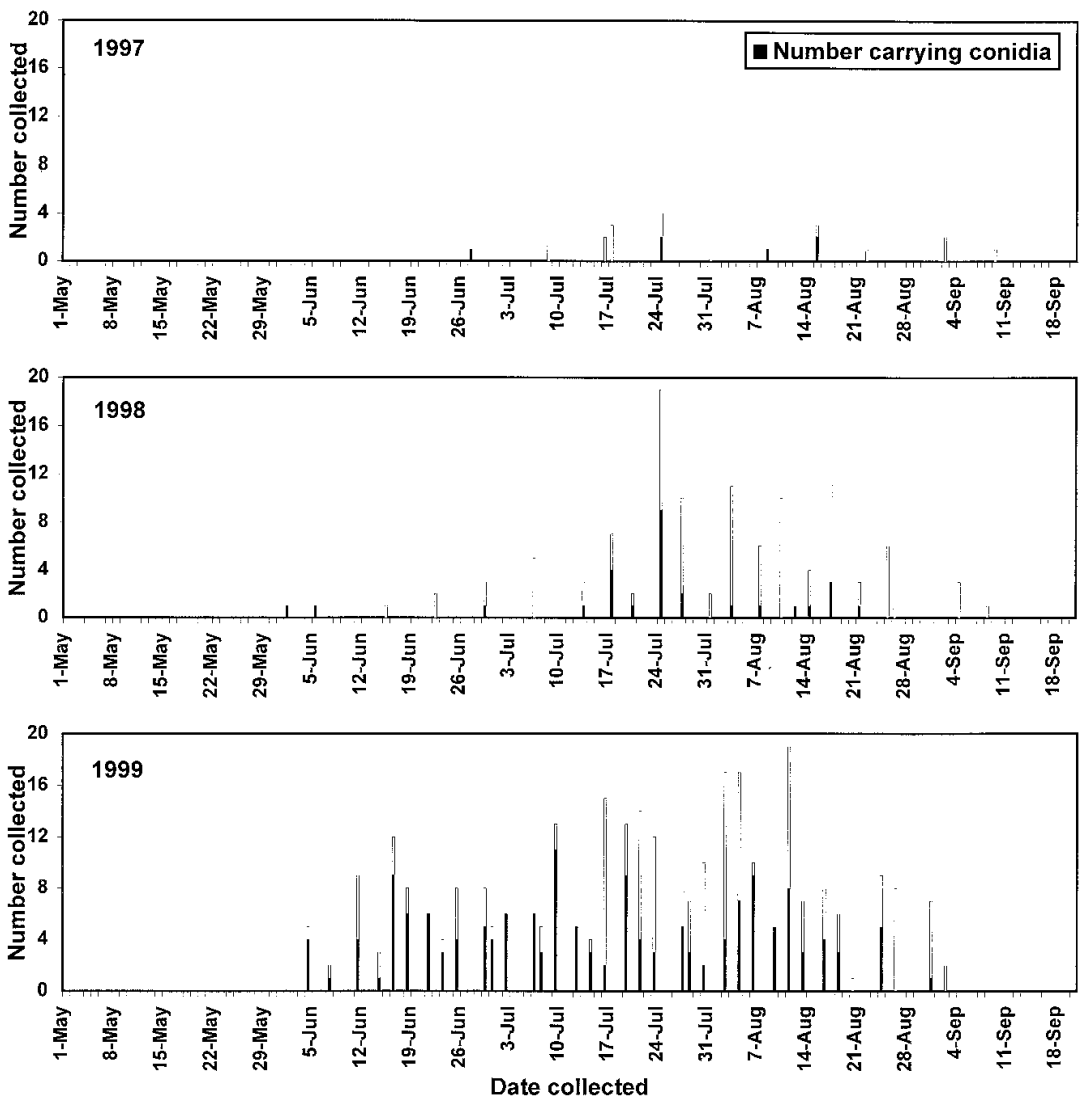

Fig. 2. Numbers of Hyperplatys maculata collected by date in Jericho, VT, in 1997, 1998, and 1999. Entire bar represents total number of individuals collected. Black portion of bar represents number of individuals found to carry conidia of Sirococcus clavigignenti-juglandacearum. were greatest during that period. We found this beetle only rarely on dead butternut branches on the ground. The females were observed to oviposit in new shoots and swollen bases of leaf rachises of butternut, and larvae developed and tunneled in the shoot and rachis tissues.

In 1997, we collected 11 nitidulids from cankers on freshly cut butternut trees, as early as late April, and 39 from live crowns or directly from wounds made by $C$. juglandis on new shoots later in the season (Tables 1 and 3). Of these, only one of the nitidulids from a canker carried conidia. In 1998 , of the 778 vials of nitidulids collected from early May through early October, over $94 \%$ were from baited traps, and $2 \%$ of these were infested with the fungus. Less than $2 \%$ of the nitidulids collected in 1998 were from tree crowns, and none of these beetles carried conidia. About $4 \%$ of the nitidulids collected in 1998 were from dead butternut logs and branches on the ground, and only one individual carried conidia. Both years, we did not identify the beetles to species and lumped all individuals together as Nitidulidae (Table 1). However, in 1998, we also collected Glischrochilus vittatus (Say) (Coleoptera: Nitidulidae) mostly from butternut logs in Berlin and recorded this species separately from the other nitidulids (Table 1). Of the $13 G$. vittatus collected, about one-third carried $\leq 2,000$ conidia. In 1999, we identified the five other nitidulids we had been collecting in addition to G. vittatus: Cryptarcha ampla Erichson, Glischrochilus fasciatus (Olivier), G. quadrisignatus (Olivier), G. sanguinolentus (Olivier), and G. siepmanni W.J. Brown. Six to seven percent of $C$. ampla and G. sanguinolentus were carrying the pathogen in 1999 (Table 1). Thirteen percent of the $G$. sanguinolentus collected were from live trees, and one-third of these individuals carried the fungus (Table 3). Spore numbers carried by $C$. ampla could not be estimated, but one individual of $G$. sanguinolentus was found to carry about 800 conidia. Nitidulids were also found to carry conidia of $M$. $o b$ longum.

\section{DISCUSSION}

We found several species of beetles closely associated with diseased butternut trees on two sites in northern Vermont. Many were in close contact with fruiting structures of $S$. clavigignenti-juglandacearum and frequently carried large numbers of conidia. Our technique for washing, isolating, and quantifying conidia from the beetles had its limitations. Spores may not always have dislodged from the exoskeletons or may have clumped together to make counting difficult. However, determining exact numbers of conidia on the beetles is not as important as appreciating the relative abundance of spores rinsed from certain beetle species and the consistently high frequency of infestation of 
these beetles over the 3-year period. We expect that our findings may be applicable throughout most of the range of butternut. Katovich and Ostry (13) found many of the same beetle species in a survey of butternut in Minnesota and Wisconsin, and they isolated the pathogen from some of those beetles.

According to Leach (14), effective insect vectors must be intimately associated with the diseased host on which the fungus is sporulating and with healthy host tissue in such a way that the fungus is successfully transmitted and causes infection. Whether any of the beetles we found carrying the butternut canker fungus are consistently transmitting conidia to healthy tissue or susceptible wounds on butternut is still uncertain. However, many of these beetles were found in living crowns of butternut. Beetles carrying the greatest numbers of conidia most frequently were those associated with dead butternut tissue upon which the fungus was prolifically fruiting. We believe Astylopsis macula, Acoptus suturalis, E. parochus, and H. maculata do not preferentially seek out healthy host tissue for feeding or breeding at any stage of their development $(2,3,8,21)$. They may, however, fly to or crawl on healthy tissues as they move from place to place and may inadvertently deposit conidia in wounds or other bark openings that may serve as infection courts.

Astylopsis macula and H. maculata overwinter as larvae beneath the bark of dead stems, logs, and large-diameter branches and emerge as adults in early to mid-summer. By late summer, females oviposit in the bark of dead stems and branches. Other tree hosts reported for both beetles include: basswood (Tilia sp.), chestnut (Castanea sp.), dogwood (Cornus sp.), hickory (Carya sp.), maple (Acer sp.), oak (Quercus sp.), and other hardwoods (15); and it is conceivable that populations of these beetles are being maintained by host species other than butternut. The geographic range for both cerambycids extends throughout the range of butternut in the United States (6).

E. parochus is reported to feed and breed only in butternut and black walnut (Juglans nigra L.) (2,3). By mid-summer, females have oviposited in dead logs and large-diameter branches of butternut, and larvae pupate and adults emerge by early fall. They probably overwinter in the soil or duff layer; however, this remains unknown.

Acoptus suturalis presumably survives in the dead bark and wood of various hardwoods, such as beech (Fagus sp.), chestnut, oak, and sycamore (Platanus sp.) $(3,21,24)$. However, our limited observation of this insect offers little new insight about its ecology except for its association with diseased butternut.

We believe the four beetles mentioned above feed on stromatal columns and
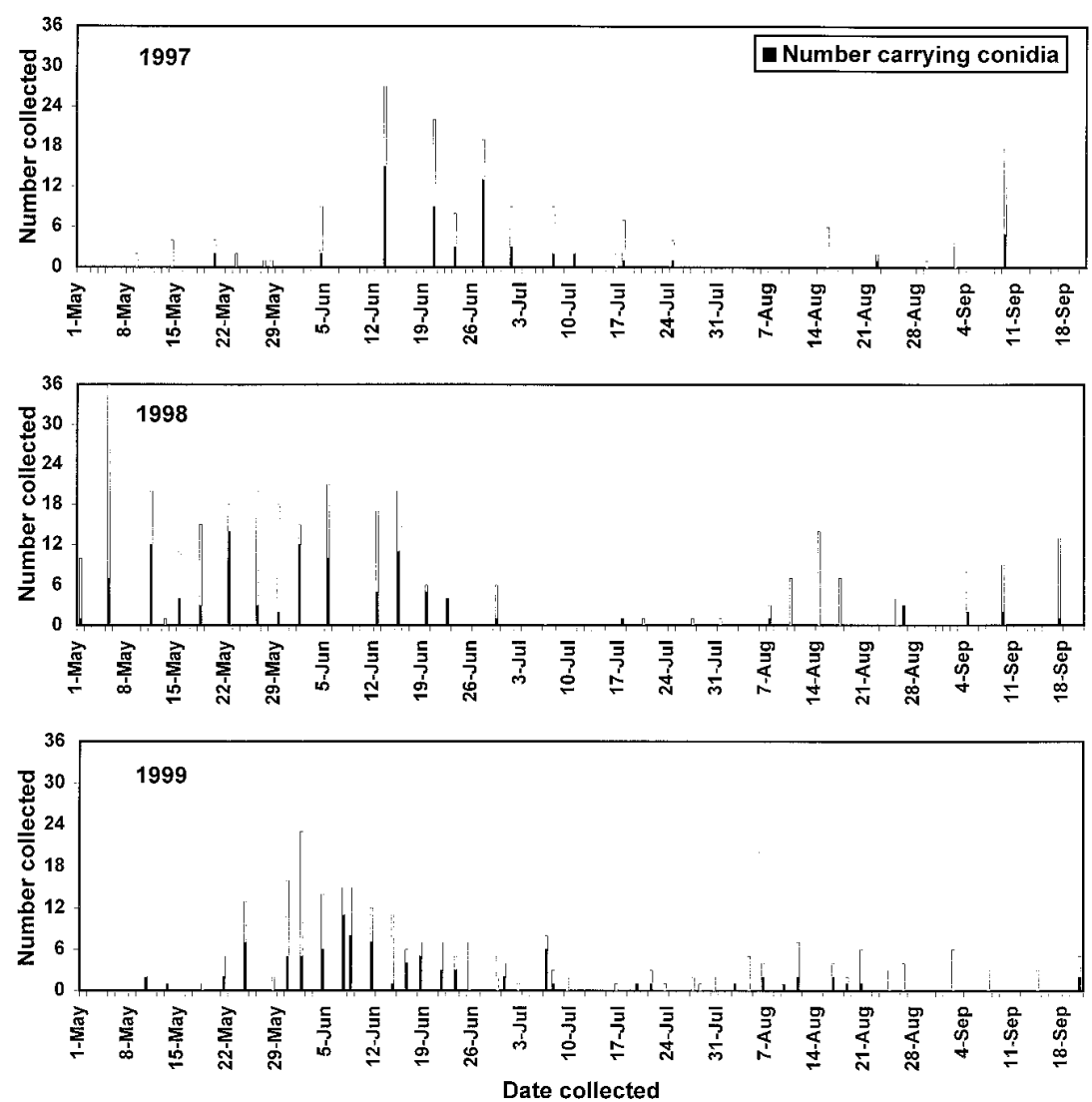

Fig. 3. Numbers of Eubulus parochus collected by date in Jericho, VT, in 1997, 1998, and 1999. Entire bar represents total number of individuals collected. Black portion of bar represents number of individuals found to carry conidia of Sirococcus clavigignenti-juglandacearum.
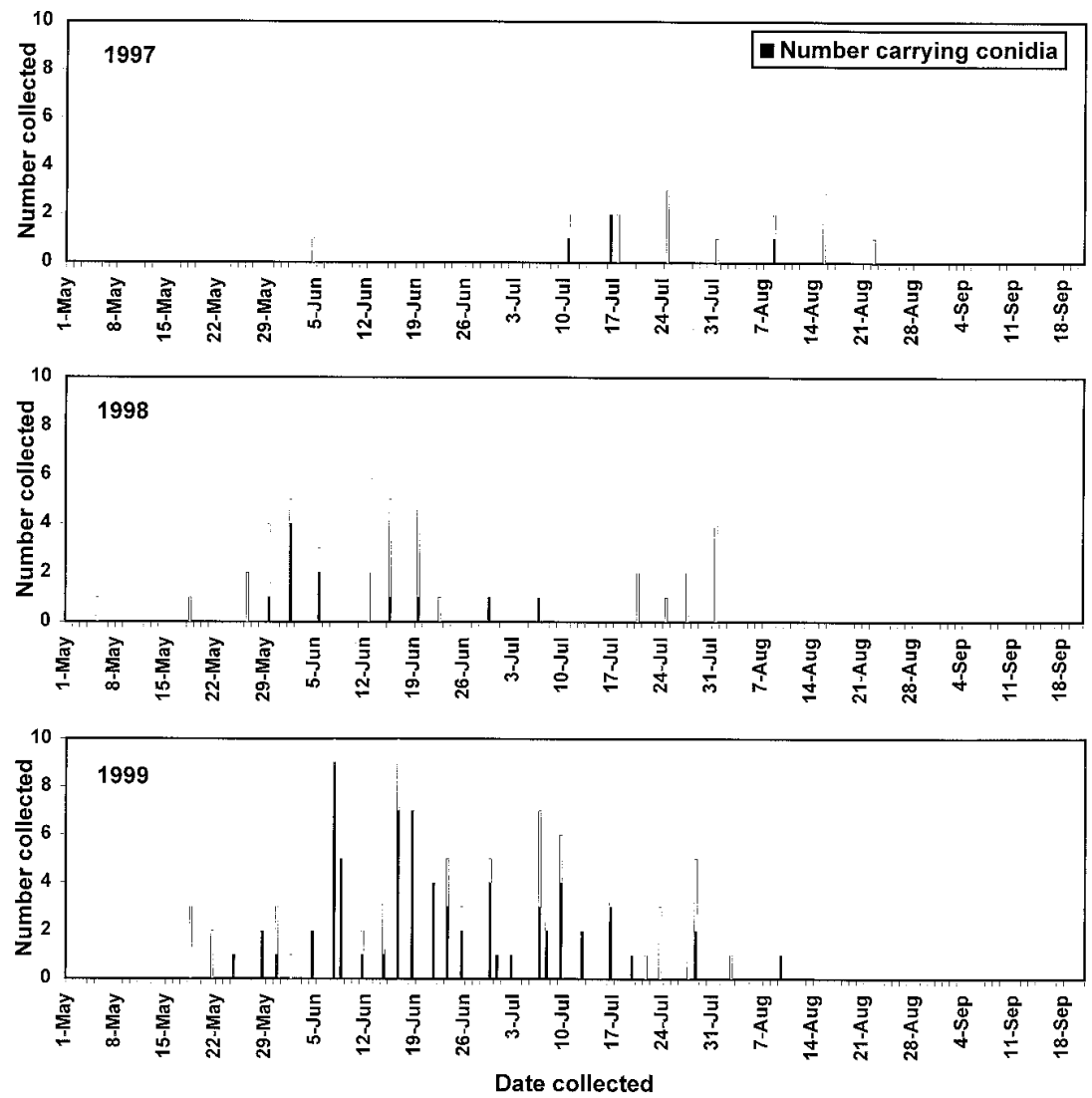

Fig. 4. Numbers of Acoptus suturalis collected by date in Jericho, VT, in 1997, 1998, and 1999. Entire bar represents total number of individuals collected. Black portion of bar represents number of individuals found to carry conidia of Sirococcus clavigignenti-juglandacearum. 
pycnidia of $S$. clavigignenti-juglandacearum as well as on fruiting bodies of $M$. oblongum. In 1999, the majority of the growing season (20 May to 15 September) received a total of $25 \mathrm{~cm}$ of precipitation in small rainfall events. Because of these severe drought conditions, we expected little sporulation by the butternut canker fungus and a reduced percentage of insects carrying conidia. On the contrary, the frequency of infestation of Acoptus suturalis, Astylopsis macula, and $H$. maculata with conidia was much greater for 1999 than for the previous 2 years, which had average precipitation (Table 1). We suspect that in 1999 , these beetles were specifically seeking out sporulating fungi, such as $S$. clavigignenti-juglandacearum and $M$. $o b$ longum, upon which to feed and derive essential moisture during this drought period. In so doing, they may have become more heavily infested both internally and externally with conidia than in the previous 2 years. Lack of precipitation may also have increased spore retention on and in the pycnidia as well as on the exoskeletons of these beetles.

Astylopsis macula has been reported to feed on pycnidia, perithecia, and conidia of Cryphonectria parasitica (Murr.) Barr (=Endothia parasitica (Murrill) P.J. Anderson \& H.W. Anderson), the cause of chestnut blight, and to carry over 300,000 viable spores of the fungus $(5,23,25)$, which is very similar to our observations of $A$. $m a c$ $u l a$ and its association with the butternut canker fungus. Acoptus suturalis has also been found associated with cankers on American chestnut (Castanea dentata (Marsh.) Borkh.) and to carry C. parasitica $(21,23)$. H. maculata has been reported to feed on fruiting bodies of Endothia sp., which was growing as a saprophyte on the dead bark of butternut and other tree species (8). Although these beetle species are predominately bark-feeders, they are apparently also mycophagous and therefore may be involved in passive dissemination of fungi, including $S$. clavigignentijuglandacearum. Whether conidia of this fungus will pass through the digestive tracts of these beetles and remain viable is unknown. However, Leach (14) stated that most fungal spores when passing through the intestine of phytophagous insects remain uninjured.

The adults of one or more of these four beetle species (Acoptus suturalis, Astylopsis macula, E. parochus, and H. maculata) could be found throughout the spring and summer actively feeding or breeding on butternut and carrying conidia (Figs. 1 to 4). Thus, opportunity for infection of butternut via beetle-vectored spores exists throughout the growing season. The butternut canker fungus is reported to continue colonizing and sporulating on dead tissue for about 2 years (28). Since these beetles have been observed to frequent dead tissue, long periods of sporulation provide ample opportunity for visiting beetles to become infested. We also speculate that we found these beetles in crowns of live trees because they were attracted to the dead tissue and the sporulating structures of various fungi. By moving from logs and dead branches on the ground to recently killed branches within tree crowns, these beetles may be inoculating both living and recently dead tissue with conidia of $S$. clavigignenti-juglandacearum, which then colonizes the bark and sporulates, thus increasing inoculum within crowns of living trees. Conidia may then be disseminated throughout the crowns by rain splash or other mechanisms. These four beetle species were also frequently infested with M. oblongum and therefore may play a role in transmitting conidia of this fungus, the cause of Melanconis dieback of stressed branches of butternut.

The butternut curculio was commonly found associated with living shoots in the crowns of butternuts and was rarely found on dead or declining tissue that would harbor conidia. A small percentage of these beetles carried low numbers of conidia, but it is possible that these spores, although carried infrequently, would be sufficient to successfully infect healthy or freshly wounded tissue of butternut. The curculio becomes active in the spring when it feeds on new shoots of butternut and black walnut. Females also chew oviposition pits in newly formed shoots, leaf rachises, and maturing fruit; and developing larvae tunnel into host tissue before dropping to the ground to pupate. Adults emerge in late summer and return to tree crowns to feed before overwintering in the soil (4). We have isolated the butternut canker fungus from curculio feeding wounds (1) and believe wounds formed by the curculio during feeding and oviposition are prime infection courts for conidia that may be transported by rain splash or by insects.

Trapping nitidulids was not necessarily an adequate method to determine percentage of nitidulids infested with the butternut canker fungus, because the beetles were funneled into the base of the trap and could contaminate each other. Rather, trap collections served to inform us of the species of nitidulids common to the sites. More significant were the nitidulids we observed burrowing inside oviposition wounds of the curculio and crawling in oozing butternut cankers. Katovich and Ostry (13) also found nitidulids associated with the fruiting structures of $S$. clavigignentijuglandacearum. It is well known that certain species of nitidulids are attracted to the fruity odor of fungal mats produced by the oak wilt fungus beneath the bark, where the beetles feed, breed, and become contaminated with ascospores and conidia of the fungus $(9,11)$. Nitidulids then fly to fresh wounds on healthy oak trees and transmit the fungus, causing new infections. Although the percentage of nitidulids we found carrying conidia was low (Table 1 ), it is comparable to some reports for nitidulid vectors of the oak wilt fungus (12,31). Nitidulids could be important vectors of the butternut canker fungus if they move from sticky, sporulating structures to wounds made by the curculio or other wounding agents on new shoots and branches of butternut.

Each of the beetles we studied could play a role in dissemination of $S$. clavigignenti-juglandacearum throughout the range of butternut; however, additional study is necessary to determine the efficiency of each potential vector. Since the fungus has been found naturally infecting black walnut and heartnut (Juglans ailantifolia var. cordiformis) $(18,20)$, and a number of other species of Juglans are susceptible when inoculated (19), the insect vector relationships we described may be of concern if the fungus is ever found in areas where other Juglans species are grown outside the range of butternut. Many of the possible beetle vectors we found are known to feed and breed in hosts besides butternut and have the potential to spread the pathogen to other Juglans species.

\section{ACKNOWLEDGMENTS}

This research was funded in part by the USDA McIntire-Stennis Cooperative State Research Program, the University of Vermont, the Vermont Department of Forests, Parks and Recreation (USDA Focus Funding Program), and the Northern Nut Growers Association, Inc. We thank A. D. Bergdahl, J. Hayden, and N. R. Forbes for field and laboratory assistance and R. T. Bell for confirming our beetle identifications. Beetle species determinations made prior to 1997 were confirmed by D. E. Bright and S. Laplante, Agriculture and Agri-Food Canada. We thank G. J. Hawley and P. $\mathrm{G}$. Schaberg for their presubmission reviews of this manuscript.

\section{LITERATURE CITED}

1. Bergdahl, D. R., and Halik, S. 1998. The butternut canker fungus recovered from insects collected on Juglans cinerea. Pages 133137 in: Foliage, Shoot and Stem Diseases of Trees. Proc. IUFRO WP 7.02.02 Meeting, Quebec City, May 25-31, 1997. G. Laflamme, J. A. Berube, and R. C. Hamelin, eds. Natural Resources Canada, Sainte-Foy, Quebec, Canada.

2. Blatchley, W. S., and Leng, C. W. 1916 Rhynchophora or Weevils of North Eastern America. Nature Publishing Co., Indianapolis, IN.

3. Chittenden, F. H. 1890. Notes on the habits of some species of Rhynchophora. Entomol. Am. 6:167-172.

4. Corneil, J. A., and Wilson, L. F. 1979. Life history of the butternut curculio, Conotrachelus juglandis (Coleoptera: Curculionidae), in Michigan. Great Lakes Entomol. 14:13-15.

5. Craighead, F. C. 1912. Insects contributing to the control of the chestnut blight disease. Science $36: 825$.

6. Dillon, L. S. 1956. The nearctic components of the tribe Acanthocinini (Coleoptera: Cerambycidae) Part I. Ann. Entomol. Soc. Am. 49:134-332.

7. Furnier, G. R., Stolz, A. M., Mustaphi, R. M., and Ostry, M. E. 1999. Genetic evidence that butternut canker was recently introduced in North America. Can. J. Bot. 77:783-785.

8. Gardiner, L. M. 1961. Immature stages and 
biology of Hyperplatys spp. (Coleoptera: Cerambycidae) in eastern Canada. Can. Entomol. 93:1011-1016.

9. Gibbs, J. N., and French, D. W. 1980. The transmission of oak wilt. U.S. Dep. Agric. For. Serv. Res. Pap. NC-185.

10. Halik, S., and Bergdahl, D. R. 1996. Sirococcus clavigignenti-juglandacearum isolated from beetles collected from Juglans cinerea. (Abstr.) Phytopathology 86:S122.

11. Juzwik, J., and French, D. W. 1983. Ceratocystis fagacearum and $C$. piceae on the surfaces of free-flying and fungus-mat-inhabiting nitidulids. Phytopathology 73:1164-1168.

12. Juzwik, J., and French, D. W. 1986. Relationship between nitidulids and Ceratocystis fagacearum during late summer and autumn in Minnesota. Plant Dis. 70:424-426.

13. Katovich, S. A., and Ostry, M. E. 1998. Insects associated with butternut and butternut canker in Minnesota and Wisconsin. Great Lakes Entomol. 31:97-108.

14. Leach, J. G. 1940. Insect Transmission of Plant Diseases. McGraw-Hill Book Co., New York.

15. Linsley, E. G., and Chemsak, J. A. 1995. The Cerambycidae of North America, Part VII, No. 2: Taxonomy and Classification of the Subfamily Lamiinae, Tribes Acanthocinini Through Hemilophini. University of California, Berkeley.

16. National Oceanic and Atmospheric Admini- stration, National Climatic Data Center. 1997. Local climatological data, Burlington International Airport, Burlington, Vermont. MaySeptember, 1997. NOAA.

17. Nicholls, T. H. 1979. Butternut canker. U.S. Dep. Agric. For. Serv. Gen. Tech. Rep. NC-52.

18. Ostry, M. E. 1997. Sirococcus clavigignentijuglandacearum on heartnut (Juglans ailantifolia var. cordiformis). Plant Dis. 81:1461.

19. Ostry, M. E. 1998. Butternut canker in North America 1967-1997. Pages 121-128 in: Foliage, Shoot and Stem Diseases of Trees. Proc. IUFRO WP 7.02.02 Meeting, Quebec City, May 25-31, 1997. G. Laflamme, J. A. Berube, and R. C. Hamelin, eds. Natural Resources Canada, Sainte-Foy, Quebec, Canada.

20. Ostry, M. E., and Katovich, S. 1997. First report of Sirococcus clavigignentijuglandacearum on black walnut. Plant Dis. 81:830.

21. Pakaluk, J., and Anagnostakis, S. L. 1997. Acoptus suturalis LeConte (Coleoptera: Curculionidae: Zygopinae), a potential vector of the chestnut blight fungus, Cryphonectria parasitica (Murrill) Barr, in the eastern United States. Proc. Entomol. Soc. Wash. 99:583-584.

22. Renlund, D. W. 1971. Forest pest conditions in Wisconsin. Wisconsin Department of Natural Resources Annu. Rep.

23. Russin, J. S., Shain, L., and Nordin, G. L. 1984. Insects as carriers of virulent and cyto- plasmic hypovirulent isolates of the chestnut blight fungus. J. Econ. Entomol. 77:838-846.

24. Sleeper, E. L. 1963. A study of the Zygopinae (Coleoptera: Curculionidae) of America north of Mexico, I. Southern Calif. Acad. Sci. Bull. 62:209-220.

25. Studhalter, R. A. 1914. Insects as carriers of the chestnut blight fungus. Phytopathology 4:52

26. Tisserat, N. A., and Kuntz, J. E. 1981. Epidemiology of butternut canker. North. Nut Grow. Assoc. Annu. Rep. 72:75-80.

27. Tisserat, N. A., and Kuntz, J. E. 1983. Dispersal gradients of conidia of the butternut canker fungus in a forest during rain. Can. J. For Res. 13:1139-1144.

28. Tisserat, N. A., and Kuntz, J. E. 1983. The etiology and epidemiology of butternut canker. North. Nut Grow. Assoc. Annu. Rep $74: 30-36$

29. Tuite, J. 1969. Plant Pathological Methods: Fungi and Bacteria. Burgess Publishing Co. Minneapolis, MN.

30. Williams, R. N., Ellis, M. S., and Keeney, G. 1994. A bait attractant study of the Nitidulidae (Coleoptera) at Shawnee State Forest in southern Ohio. Great Lakes Entomol. 27:229 234.

31. Yount, W. L., Jeffery, A. R., and Thompson, H. E. 1955. Spores of Endoconidiophora fagacearum on the external surface of the body of nitidulids. Plant Dis. Rep. 39:54-57. 